\title{
Research on the Teaching Reform of the Basic Course of Art Design
}

\author{
Nannan Zhang ${ }^{1, \text { a }}$ \\ ${ }^{1}$ Changchun Sci-Tech University, Changchun, 130600, China \\ ${ }^{a}$ email
}

Keywords: Art design; Basic course; Teaching reform; Integration

\begin{abstract}
At present, there is a gap between the traditional basic course teaching of art design specialty and its training target of new era, and there is a lack of necessary links between basic and specialized courses. The basic course of art college is an important part and the foundation of professional teaching. The teaching task of innovative talents and skilled talents in colleges and universities is becoming more and more arduous, which brings a severe test to the teaching of basic courses in art design. For cultivating new talents under the new situation, this paper first analyzed the college of art design curriculum teaching problems, and then put forward the reform measures of university art design course.
\end{abstract}

\section{Introduction}

With the continuous reform and development of art design education courses, at present, most art colleges adopt different reform methods and approaches for the teaching of basic courses in art design according to the characteristics of various disciplines, and set up different research directions for different types of majors in higher art design colleges. Therefore, it is necessary to set up corresponding basic training courses according to different majors. Through the reform of teaching practice, it will helps students of art design college in the university to learn from the basic course of modeling rapidly and combine with the study of the following courses. Moreover, it will achieve the integration of basic courses and specialized courses smoothly. In addition, it can also better serve the students of art design to understand the modeling and design, and better grasp the creation of the formal beauty of art design, so that to do a good job of basic knowledge accumulation and professional skills training for the future design direction. As a result, the creative thinking of art design concept becomes more pioneering and innovative, and eventually grew into a comprehensive art design talents.

\section{Problems Encountered in the Teaching of Basic Courses of Art Design}

Most colleges are still using the traditional art education method. Most of China's design institutions have been transformed from traditional arts and crafts. In the basic course of design education, the traditional art education still has a continuation. The most obvious is the modeling of basic courses, drawing and color teaching. Most of the colleges and universities have been used in teaching methods of painting, emphasizing the description and representation and picture structure with ignoring the shape and color, which is not conducive to the cultivation of students' creative thinking, individual thinking and aesthetic consciousness. In general, students who choose art majors learn basic colors, sketches and drawings in high school, and some of these students are excited by the desire for knowledge to enter college. The university is a continuation of make-up class teaching mode. They will have some resistance, because they think that they are learning to design at colleges and universities. The biggest difference between design education and art education is art training, emphasizing modeling, 
expressive skills and color sense. The design education emphasizes the rational, scientific form analysis and the law of aesthetics, and the training of color law. The students lack scientific and rational understanding of style and color, and the negative influence on the teaching of professional design can be imagined.

The three major courses are badly in need of reform. The current design basic course regarding the three-dimensional composition, color composition and plane composition as the design technology class phenomenon is very common. After the reform and opening up in 1978, and after the introduction of the three major courses of the Bauhaus system from Japan and Hong kong, a series of achievements have been made in solving the central task of the basic education of art and design. That is, the innovation of form has achieved a series of achievements. At present, the composition course has also adopted the course in 30 years ago. The teaching direction is seriously deviated. In Bauhaus, the formation of homework can be directly translated into design works, and the transformation capability in China is still a long way to go. In the process of teaching, teachers emphasize skill and a lot of training. The student's constituent work becomes a mechanical depiction without thinking and a technical organization of symbolic elements. They fall into the format, understanding of stylized and formulaic shackles, and the learning process is boring with lack of creativity. The results of education have led to the formation of courses that do not contribute much to their later professional design courses and actual project design.

The obsolescence of teaching methods. What we need to think about is how to improve students' creative thinking ability, which is the most urgent problem in art design course. Most of the basic design courses in colleges and universities still adopt the inculcation style of classroom teaching with teachers as the main body. Moreover, they only pay attention to teaching knowledge and skills training, and do not pay attention to the cultivation of students' creative thinking ability. As a result, the students' interest in learning is not effectively stimulated with low initiative of seeking knowledge and poor imagination and week exploration ability. The design potential of students has not been scientifically and reasonably excavated in the initial stage, and even stifled. It has hindered the development of students' learning ability, discovery ability, judgment, aesthetic ability and creative ability.

Disconnect from social needs with lacking regional characteristics. In China's higher education, art design is one of the most popular majors. There are more than 600 colleges and universities specializing in designing art courses, and most of them have the same basic design courses, such as sketch, color, three components and traditional pattern, etc. This consistency and repetition reflect the disconnection between the design course and the local economy, life and local culture. Students are not familiar with regional values and outlook, local folk arts and crafts and materials. The basic training has not been effectively connected with the product creation of local enterprises, and the design does not really meet the needs of local enterprises. This state of affairs needs to be improved urgently.

\section{The Reform Measures of the Basic Courses of Art Design College}

Revising the teaching objectives - from tradition to innovation, from basics to design. Strengthening the basic art teaching reform in colleges and universities is the primary condition and the inevitable requirement of training students' design ability and creative thinking. To reform the basic teaching of art design, we should begin with traditional teaching. We should strengthen practical teaching and combine the development and orientation of each design specialty; moreover, we should change the teaching link and setting up, focusing on teaching target of "from tradition to innovation, from basics to design". further, we should systematically adjust the content, methods and process of the teaching. The teaching content of traditional design professional tightly confined to the traditional sketch, color basic modeling training, so it is completely out of line with the design content and 
imprisons the creative thinking of the students. The basic course of art and design mainly covers the relevant theoretical knowledge of aesthetics common sense, aesthetics history, the law of formal beauty, graphic originality, and the basis of integrated design. The teaching reform must be closely related to the characteristics and similarities among different specialties, so as to train creative talents. The teaching reform must be guided by the direction of the major research, and firmly grasp the groundwork, cohesion and basic role of the basic design curriculum in the professional design. The basic teaching curriculum should focus on the design of professional theory, professional design skills and innovative thinking ability, practical ability training.

Based on the cultivation of innovative talents in the new situation, we put forward the art design professional creative talents training objectives, including "people-oriented", "ability based" and "Innovation led", highlighting the students' professional ability as the center of teaching practice reform. The education mode of art subject undertakes the task of training talents at the end of undergraduate education and the front of specialized education. By giving full play to the role of basic teaching, the teaching of knowledge can be organically integrated with the improvement of students' creative ability and the formation of comprehensive quality. This implements a multi dimensional training in the same learning environment with a wide range of abilities and skills, multiple specialties and disciplines, similar occupations and a variety of ways of thinking. Through cultivation of basic disciplines knowledge and vertical and horizontal abilities, we have completed the training of students' creative ability in multi - discipline art design. Moreover, this enables students to improve and develop in their knowledge, ability, quality, emotion and so on, and eventually form their own unique career, employment and entrepreneurial ability, so that to become masters of the fate of their career.

Changing teaching ideas - from traditional thinking to creative thinking. The basic course of art design major aims to train students' thinking ability and innovative thinking ability, and must not be regarded as the only training of body painting and expression techniques. This requires innovative methods and ideas to reform the traditional teaching model. The traditional teaching methods are obviously unable to meet the development of today's design teaching. The connotation of art design is being replaced by new ideas, new materials and new forms. Only truly understand and grasp the basic art curriculum, can students play the greatest potential in training, so that to pave the way for professional training. Targeted teaching reform should reflect the modeling foundation of art design and it should have the necessary professional skills and artistic accomplishment. Changing the teaching methods of blindly follow the traditional painting in old teaching model and ignoring the further connection between thinking and practice in professional design courses are the wrong ways. In the course of the study of the inheritance and innovation, more scientific and complete creative teaching thinking further explains that the core of the design lies in innovation. The key to design basic course is to establish the teaching method and model of student oriented and teacher led. The curriculum construction should pay attention to the cultivation of students' design and innovative thinking mode and the cognition of polysemy of form and color. We should train students in all directions and angles to use divergent thinking and to transcend natural objects, and to reveal the rules of modeling and discover the potential aesthetic value. We should pay attention to the cultivation of students of observation based modeling sharp, accurate expression and thinking ability from the concrete to the abstract. Therefore, students can master the thinking ways and rules from basic modeling to professional creative design from its own professional characteristics. Moreover, they can get inspiration and creativity from practice, which will lay a solid foundation of modeling thinking and hand-painted performance for the study and work of art design specialty in the future.

\section{Summary}

The traditional teaching model in most colleges and universities in China has a strong singleness. Knowledge 
learning is mainly taught in a professional in duplicate, which is lack of inherent connection with other art design specialty. In the emphasis on knowledge learning at the same time, we have ignored the different degree of practical ability and creative thinking training, resulting in personnel training to narrow and one-sided, and students are facing more and more pressure in the job market. Therefore, in the process of study on the teaching reform in basic art teaching, we should strive to construct innovative thinking, so that to form the teaching mode and method of cross linking basic curriculum and different professional design and make full use of characteristics of the various design disciplines. We should also vigorously expand the channels for talent training, which is an effective way to deepen the teaching reform of art and design specialty and to improve the quality of teaching.

\section{Acknowledgement}

Higher education scientific research project of Jilin Provincial Institute of higher education in 2017: Research and practice of teaching reform in the course of art design specialty in Applied Undergraduate Colleges (subject number: JGJX2017D273)

\section{References}

[1] Zhang Yuanyuan. Reform and Exploration on Art Design Sketch Curriculum Basic Teaching[J]. Shanxi Agricultural Economics, 2017, (08): 85.

[2] Li Qingdong. Analysis and Exploration of the Path of Reform on the Current Situation of Basic Courses in Art Design[J]. Art Education, 2014, (07): 241-242.

[3] Liu Yanping, Liu Mingsheng. Exploration of the Teaching Reform of the Basic Course of Art Design[J]. Art and Design (Theory), 2013, (11): 155-157.

[4] Li Xiaohui. Exploration and Research on the Teaching of Integrated Arts Courses[J]. Art Hundred, 2010, (S1): 386-388.

[5] Xu Qiaonan. Research on the Teaching of Designing Basic Sketch Course[D]. Hunan Normal University, 2009.

[6] Gao Wei. A Study on the Basic Curriculum of Art Design[D]. Southwestern University, 2009.

[7] Lan Jiang Ping. Exploration of Teaching Reform of Basic Courses of Art Design[J]. The Science Education Article Collects ( late Publication), (03): 42-43. 